\title{
Lakes of the Jom-Bolok Volcanoes Valley in the East Sayan Mts., Baikal region:
}

\section{Morphogenesis and potential for regional paleoenvironmental studies}

\author{
Alexander SHCHETNIKOV ${ }^{1,2,3}$, Elena V. BEZRUKOVA ${ }^{2,4}$ \\ 1. Institute of the Earth's Crust SB Russian Academy of Sciences, Irkutsk 664033, Russia; \\ 2. Vinogradov Institute of Geochemistry SB Russian Academy of Sciences, Irkutsk 664033, Russia; \\ 3. Irkutsk State University, Irkutsk 664033, Russia; \\ 4. Institute of Archaeology and Ethnography SB Russian Academy of Sciences, Novosibirsk 630090, Russia
}

\begin{abstract}
This article describes the lake basins of the Jom-Bolok volcanic region in the East Sayan (the largest manifestation of the Holocene eruptions in Central Asia). The geomorphological position, origins, aspects of the structure and development are reviewed considering its sedimentary filling. The limnic morphogenesis here develops under the conditions of contrasting relief, high energy of neotectonic and exogenous processes. We established that Lake Khara-Nur, formed as a result of lava-damming of the Jom-Bolok river valley, emerged in its present form approximately 6500 years ago. A complex record on the environment and climatic changes, acquired from its sediments, made it possible to determine for the first time in this region the long-term trends in the development of the Middle and Late Holocene mountain geosystems and also the distinction of several paleogeographic stages of the formation of the natural environment. An average geochemical record resolution for the bottom sediments of the lake was made uniquely for the East Siberian lake records and is equal to 35 years, while the palynological record approximates 110 years.
\end{abstract}

Keywords: lake morphogenesis; Holocene volcanism; lava-dammed lakes; environmental change

\section{Introduction}

Jom-Bolok volcanic region is located in the eastern part of the East Sayan mountain system (Figure 1) and is attributed to one of its main oro-hydrographical nodes. Here the Kropotkin, Okinskii and Bolshoy Sayan Ridges come together, forming a huge orographic complex, bordering the Oka plateau with altitude up to $3000 \mathrm{~m}$ a.s.l. (Figure 2) and with modern glaciation. The Jom-Bolok river glacial valley drains the axis zone of this morphostructure. Its

Received: 2017-12-12 Accepted: 2018-05-03

Foundation: The Ministry of Education and Science of the Russian Federation, the State Assignment No.IX.130.3.1. (0350-2016-0026), No.IX.136.2. (0346-2016-0005); Russian Science Foundation, No.16-17-10079 (geomorphology, pollen and isotopic studies); Russian Foundation for Basic Research, No. 16-05-00586; The Project, No. 074-02-2018-334

Author: Shchetnikov Alexander, PhD and Senior Researcher, specialized in geomorphology and Quaternary geology. E-mail:shch@crust.irk.ru 
bottom is filled with trachybasalt lavas of the Hawaiian lava type with a length of $70 \mathrm{~km}$, a thickness of about $200 \mathrm{~m}$ and width of about 4 $\mathrm{km}$ and volcanic slag cones at the head of the valley fixates the primary center of eruptions (Figure 3 ) with a total volume of $16 \mathrm{~km}^{3}$ (Yarmolyuk et al., 2003). After the discovery of young volcanic formations, this region of the East Sayan is traditionally called the Volcano Valley (Kropotkin, 1867; Obruchev, Lurie, 1954).

The lava flows and volcanoes of the Jom-Bolok river valley represent the main manifestation of the Holocene eruptions in Central Asia

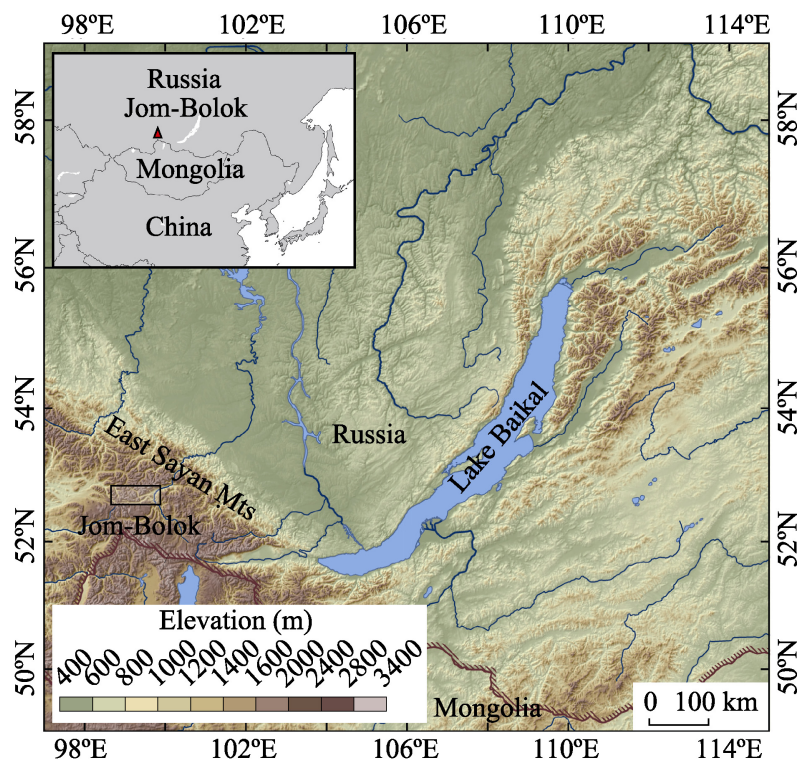

Figure 1 The Jom-Bolok volcanic region location plan, SRTM based (Yarmolyuk et al., 2003). The history of the study of this geological phenomenon has more than 150 years. At present, detailed data have been acquired on the structure, composition, sources, and mechanisms of lava flow effusions in the valley (Yarmolyuk et al., 2003; Kropotkin, 1867; Obruchev, Lurie, 1954; Adamovich, 1959; Kiselev et al., 1979). However, along with that, it was not possible to determine its chronological sequence more or less accurately. It is known that volcanic events were multiphased (Yarmolyuk et al., 2003). They began at the boundary of Pleistocene and Holocene and continued until the last millennium (Ivanov et al., 2011; Arzhannikov et al., 2017), and are probably not over yet.

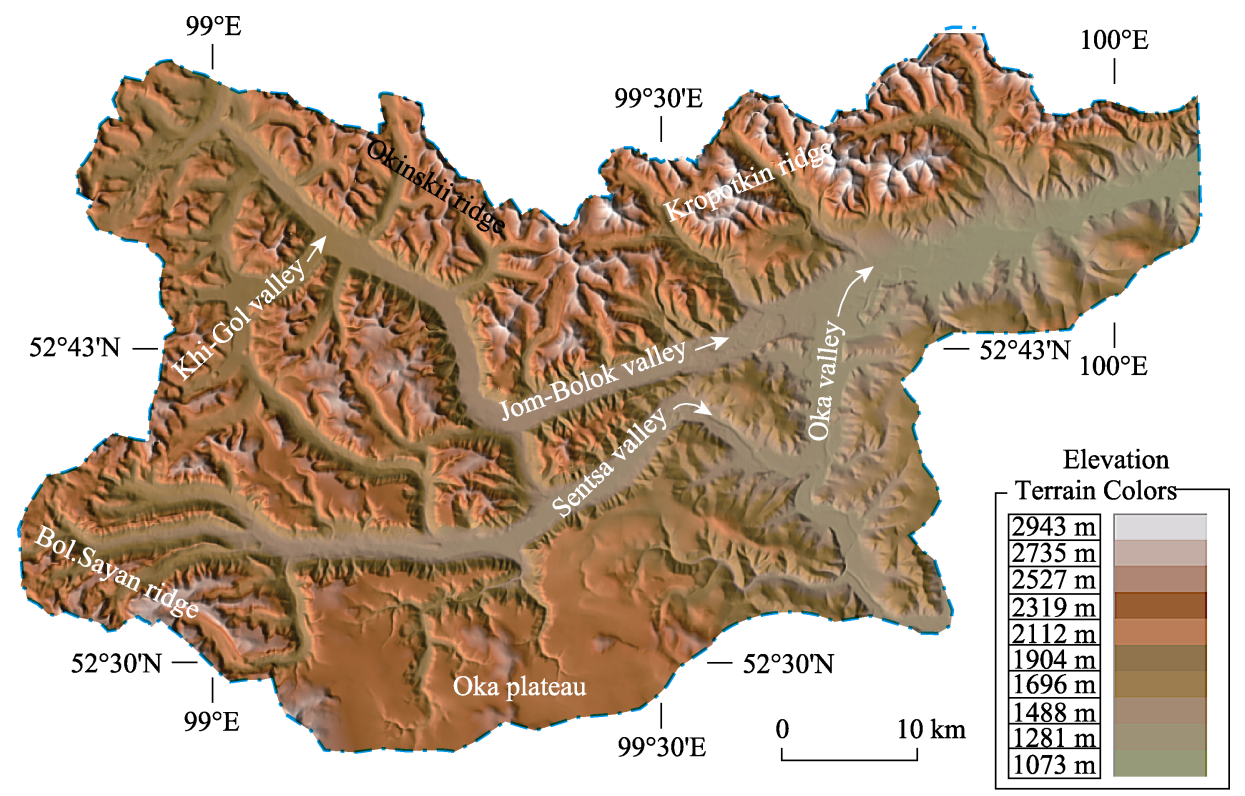

Figure 2 Digital model of the Jom-Bolok region relief, SRTM based 


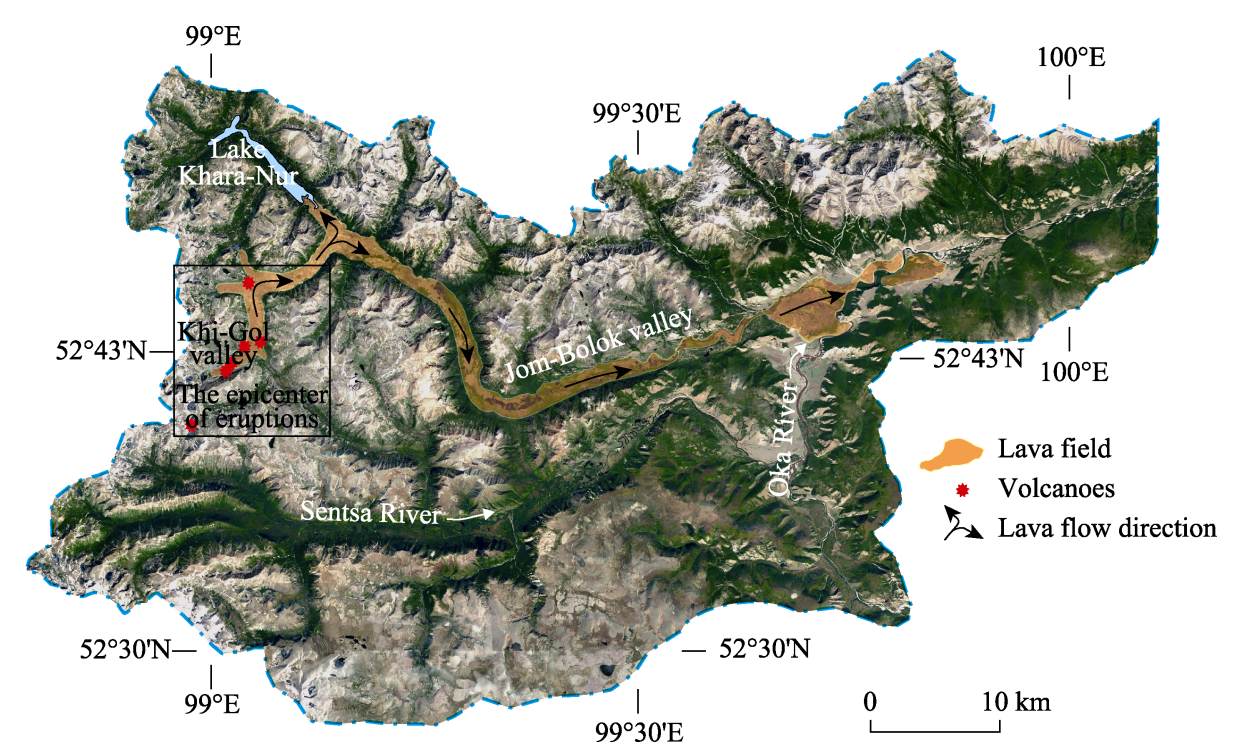

Figure 3 Space image (Image (C) 2017 DigitalGlobe) of the Jom-Bolok region with the locations of the lava flows and the volcanoes

According to Yarmolyuk et al. (2001) and Arzhannikov et al. (2012), the Late Pleistocene glaciation in this part of East Sayan during MIS 5 reached the peak phase of its development, when the Oka Plateau and the Azas Plateau were covered with layers of ice. During MIS 4, the glaciation was also significant and its scale reached the previous isotopic stage (Arzhannikov et al., 2012). In MIS2, the glaciers were still widely disseminated, but their volume was significantly reduced, and glacial processes manifested mainly in the valleys and the corries. The mean exposed ages of the glacial sediments of that time in the valleys of the Oka plateau are $16.44 \pm 0.38 \mathrm{ka} \mathrm{BP}$ and $22.80 \pm 0.56 \mathrm{ka}$ BP (Arzhannikov et al., 2012).

Late Pleistocene glaciation and the following large-scale volcanic events determined the widespread development of limnic morphogenesis processes in the Jom-Bolok region. The lakes of glacial origin are of particular importance here. In the adjoining regions, such as the Darkhad basin and in the upper parts of the Kaa-Khem River, during the periods of deglaciation large bodies of water were formed with glacial dams, their development history is related to hydrospheric cataclysmic events (Krivonogov et al., 2005; Gillespie et al., 2008; Komatsu et al., 2009). The volcanic eruptions in the valley of the Jom-Bolok river were accompanied by the formation and rupture of lava lakes, most of which remain to this day. In general, the lake basins in this region are abundant and dissimilar, their role in the structure and functioning of regional morphological landscapes is extremely high.

Because the ecosystems of the mountain water reservoirs and the processes of lithogenesis within them are very sensitive to register natural and anthropogenic changes, and the sedimentary archives of these lakes are traditional subjects for paleogeographic analysis, the study of lake basins in the Jom-Bolok River Valley is of utmost importance for the reconstruction of specific local volcanic events, including their chronology. 


\section{Research methods}

We started an expedition to the Jom-Bolok region in 2013 to carry out a joint analysis of the geomorphology of the local lake basins and their sedimentary infilling. The bathymetric studies in the water deposits were carried out using sonar Humminbird Matrix 748x3D. The bottom sediments of the lake were tested with the UWITEC gravity corer (Austria) with an internal diameter of $63 \mathrm{~mm}$.

Radiocarbon ages determined by accelerator mass spectrometry (AMS) are listed in Table 1.

Table 1 AMS radiocarbon dates from the Jom-Bolok lakes cores. Radiocarbon years before present were converted to calendar years after Ramsey (2009)

\begin{tabular}{lclcccc}
\hline \multicolumn{1}{c}{ Lake } & $\begin{array}{c}\text { Sample } \\
\text { depth } \\
(\mathrm{cm})\end{array}$ & \multicolumn{1}{c}{ Dated material } & $\begin{array}{c}{ }^{14} \mathrm{C} \text { age } \\
\text { (yr BP; } 68 \% \\
\text { range })\end{array}$ & $\begin{array}{c}\text { Cal. age } \\
\text { (yr BP; 68\% } \\
\text { range })\end{array}$ & $\begin{array}{c}\text { Laboratory } \\
\text { number }\end{array}$ & $\begin{array}{c}\text { Mean sedi- } \\
\text { mentation } \\
\text { rates } \\
(\mathrm{mm} / \mathrm{yr})\end{array}$ \\
\hline Khara-Nur & 25 & Grey-brownish soft silt & $2830 \pm 35$ & $2941 \pm 47$ & Poz-76467 & 0.08 \\
Khara-Nur & 48 & Brown compact silt & $3715 \pm 35$ & $4066 \pm 60$ & Poz-76466 & 0.2 \\
Khara-Nur & 73 & Light-gray-brownish & $4970 \pm 35$ & $5698 \pm 38$ & Poz-76465 & 0.15 \\
Khara-Nur & 93 & Brown compact silt & $5470 \pm 40$ & $6264 \pm 37$ & Poz-76603 & 0.35 \\
Khara-Nur & 127 & Peat-peaty soil & $6035 \pm 35$ & $6881 \pm 53$ & Poz-58391 & 0.6 \\
Tukhuren-Nur & 98 & Blue clay & $11350 \pm 120$ & $13209 \pm 113$ & Poz-58387 & 0.07 \\
Borik-Nur & 86 & Gray-brownish clay & $4070 \pm 30$ & $4577 \pm 93$ & Poz-58388 & 0.19 \\
Khikhushk & 87 & Grey-brownish silt & $8320 \pm 50$ & $9333 \pm 79$ & Poz-58421 & 0.09 \\
Nomto-Nur & 127 & Grey-brownish silt & $2650 \pm 30$ & $2769 \pm 22$ & Poz-58389 & 0.46 \\
Shas-Nur & 192 & Grey-brownish silt & $5245 \pm 35$ & $6019 \pm 72$ & Poz-58389 & 0.32 \\
\hline
\end{tabular}

The age values were calibrated using the calibration curve INTCAL 13 (Bronk Ramsey, 2009). The sediment is not calcareous, thus ensuring a reservoir effect, which generally complicates the precise dating of the Baikal cores (Colman et al., 1996; Demske et al., 2005), it is not a problem in the Jom-Bolok lakes. The mean sedimentation rates calculated between neighboring dates are also shown in Table 1. The Khn core age model improved significantly, compared to the one previously used (Bezrukova et al., 2016), which allowed determining more accurately the ages of damming rivers and the formation of lakes.

The magnetic properties of the sediments were studied using the MS2 Bartington magnetic susceptibility system with MS2C70 and MS2K sensors. The sediments of Lake Khara-Nur were subjected to X-ray fluorescence (XRF) analysis for each $0.5 \mathrm{~cm}$ of the upper $102 \mathrm{~cm}$ of the core, and for each $1 \mathrm{~cm}$ of the lower series in the range of 102-107 cm, forming 234 samples in total. The oxide-forming rocks $\left(\mathrm{Na}_{2} \mathrm{O}, \mathrm{MgO}, \mathrm{Al}_{2} \mathrm{O}_{3}, \mathrm{SiO}_{2}, \mathrm{P}_{2} \mathrm{O}_{5}\right.$, $\mathrm{K}_{2} \mathrm{O}, \mathrm{CaO}, \mathrm{TiO}_{2}, \mathrm{MnO}$, and $\mathrm{Fe}_{2} \mathrm{O}_{3}$ ) were determined by means of X-ray fluorescence spectrometry (Pashkova et al., 2016).

The palynological analysis was performed for each second core centimeter (Faegri et al., 1989). The calculation of the pollen taxon group's percentages (trees, shrubs, on-land herbs pollen) was made from the base sum of arboreal and non-arboreal pollen, taken as $100 \%$.

In addition, the concentration of the biogenic silica for each centimeter of the core was counted using the method of Mortlock and Froelich (1989). The content of organic matter 
was determined as losses during calcination by incineration of samples at a temperature of $550^{\circ} \mathrm{C}$ for 4 hours (Heiri et al., 2001) after preparatory drying at $105^{\circ} \mathrm{C}$ for 10 hours.

To demonstrate the changes in the natural environment, climate and vegetation of the Khara-Nur Lake basin, several widely used indexes based on pollen and geochemical data were calculated. The Dark $\mathrm{C} / \mathrm{Light} \mathrm{C}$ index is a ratio of the sum of pollen from dark conifers (Pinus sibirica + Abies sibirica + Picea obovata) with respect to the pollen sum of light conifers (Pinus sylvestris + Larix). The chemical index of alteration CIA is the most conventional one of the weathering indexes and is used to evaluate climate control in weathering processes under different conditions of natural sedimentation, including lake sedimentation (Nesbitt, Young, 1982; Minyuk et al., 2014). The zoning in Figure 11 was done using CONISS, which performs a stratigraphically constrained cluster analysis useful for zoning (for technical details, see Grimm, 1987).

\section{Modern physiographic conditions}

The remoteness from the oceans and the high elevation of the area above sea level determine a sharply continental climate of the East Sayan. According to the observation data of the meteorological stations closest to the region of Orlik and Ilchir, the climate of the Oka Plateau, where the Valley of the Volcano is located, is sharply continental, with a long and severe winter, a cool summer during which occurs most of the precipitation. The average temperature range of the warm and cold seasons reaches $50^{\circ} \mathrm{C}$. The average annual amount of precipitation approaches $430 \mathrm{~mm}$. The permafrost is found at depths from 0.2 meters to $1.5-1.7$ meters and is the cause of the high swampiness of the valleys, slopes and water divide (Solovieva, 1976).

Around the lake, the forests are dominated by siberian larch Larix sibirica, sometimes with spruce Picea obovata, Siberian pine Pinus sibirica, fir Abies sibirica.

\section{General information about the lakes}

The volcanic region of Jom-Bolok has 658 lakes. Their average size varies between 0.1-0.3 $\mathrm{km}^{2}$. The largest lake, Khara-Nur, has an area of $9 \mathrm{~km}^{2}$. The geomorphological position of the lakes is diverse: about 210 lakes are found in the bottoms of the valleys, two lakes occupy volcanic crater bottoms and more than 450 basins are attributed to the apical mountain belt (they occupy the bottom of glacial circuses).

All lake basins can be combined into 4 groups (Figure 4): determined by volcanic activity, glacial processes, postglacial fluvial processes, and complex origin. The lakes of the first group are directly associated with the lava flows and volcanoes of the Jom-Bolok River Valley. The hydrographic basins of glacial origin have a universal distribution: they are located both in the bottom of the valleys and in the apical mountain belt. The volcanic structures are located not only in the valley of the Jom-Bolok river but also in the adjoining valley of the Sentsa river. The Sentsa river bed is accompanied by multiple oxbow lakes and other floodplain water basins also attributed to volcanic activity in the valley of the Jom-Bolok river. Some lakes in the studied region were formed by a complex of relief forming processes, and their basins have a polygenetic nature, mainly of the glacial-fluvial type. 


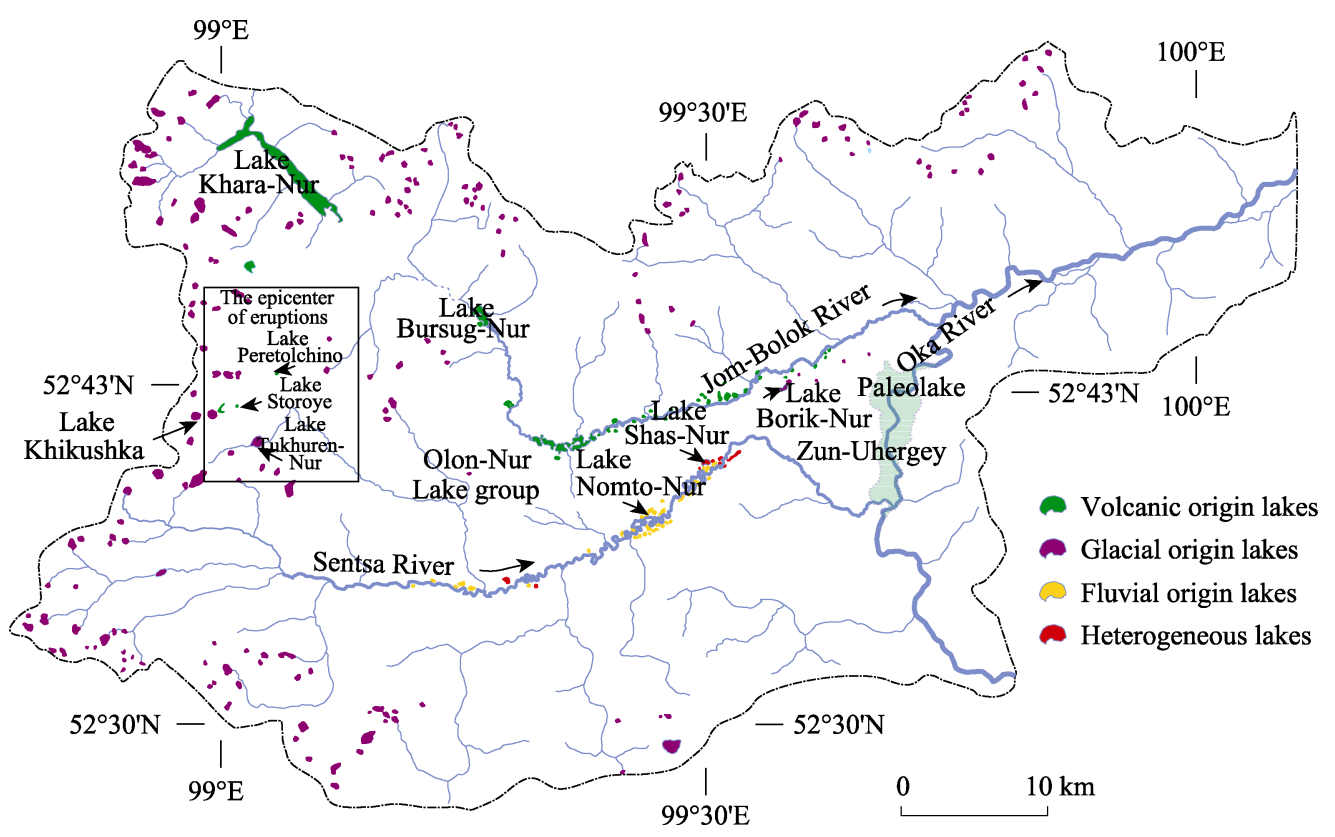

Figure 4 River and lake network of the Jom-Bolok region. The map shows the lakes with the square area above $0.05 \mathrm{~km}^{2}$, with the exception of the reservoirs within the volcano craters

\section{Results}

\subsection{Geomorphology}

\subsubsection{The lakes of volcanic origin}

Among the lakes of volcanic origin in the Jom-Bolok region lakes of lava dams, reservoirs of water in lava flow gaps and crater lakes were discovered.

Descending the valley of the Jom-Bolok River from the height of almost $2000 \mathrm{~m}$ of the Khi-Gol fold, in the upper reaches where the primary center of the eruptions is located, the lava flows sequentially close the tributary transits with lava dams. After filling the bottom of the trough of the Jom-Bolok River, the lava flows moved for almost $20 \mathrm{~km}$ towards the valley of the Oka River, stopping at a height of $1280 \mathrm{~m}$. Due to the eruptions, several stagnant water reservoirs emerged. For example, Lake Serpovidnoe $\left(0.3 \mathrm{~km}^{2}\right.$, true altitude $\left.1961 \mathrm{~m}\right)$ is located in the upper reaches of the Khi-Gol fold in the direct vicinity of the eruption center (Figure 5). The lava flow, which moved up through the valley, stopped less than $100 \mathrm{~m}$ from the girder wall of the lowest Corrie of the cirque stairway, which opens the Khi-Gol valley, filling it almost completely. The rest in front of the small lava crescent-shaped basin about $10 \mathrm{~m}$ deep filled with water, flowing from the Corrie Lake cascade. The thickness of the lava here is such that the surface of its flow, which is now a bottom of the valley, has almost the same altitude as the bottom of the lowest Corrie of the cirque stairway.

The largest lake of this type, Zun-Uhergey (see Figure 4), formed in the front part of the lava flow, where due to the eruptions the flow of the Oka river was dammed. The surface of the lake reached $19 \mathrm{~km}^{2}$ and the depth, more than $30 \mathrm{~m}$. It seems that it existed only for a short period of time. The basalt dam was breached at some point, the Oka riverbed cut with a 


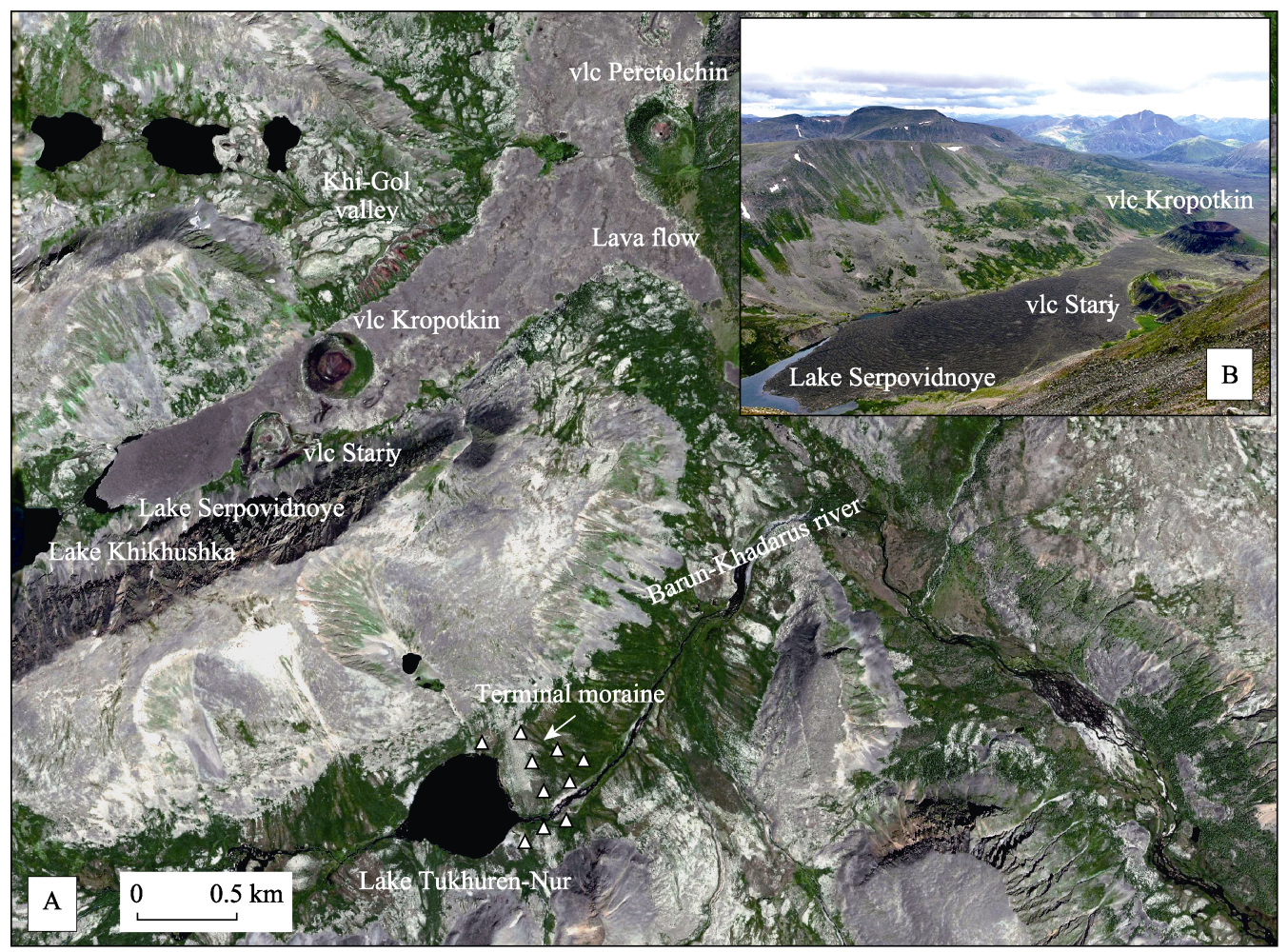

Figure 5 Epicentre of the eruptions of the Jom-Bolok River Valley in the upper reaches of the Khi-Gol fold (A, Image (C) 2017 DigitalGlobe) using Landsat space images, and its photo (B, by authors). The arrows show the directions of lava flows

narrow canyon, and the lake disappeared. Currently, the only indication of the existence of this water basin is the inclination on the lava dam, rich in sediments of "glacial flour" lakes (Arzhannikov et al., 2012).

The other water basin of this group is Lake Khara-Nur (Figures 4 and 6), preserved to this day. Not only is this one of the largest lakes of its kind, but also a key element of the lake morphosystems of the volcanic region of Jom-Bolok, which is why it is especially described in the paper.

The area of Lake Khara-Nur exceeds $9 \mathrm{~km}^{2}$, the actual altitude of the water's edge is 1651 $\mathrm{m}$, and the maximum depth is $51 \mathrm{~m}$. The water level in the lake is subject to extreme seasonal fluctuations; its amplitude reaches $20 \mathrm{~m}$ and more. We have carried out a bathymetric study of the lake bottom deposit which, together with the field observations, allowed us to determine some parameters of the geomorphological structure and its basin formation.

The Lake Khara-Nur basin consists of two sub-basins, adjoining each other almost at right angles and that occupy bottoms of different basins trough valleys. During the Late Pleistocene, the glacier cooled, descending through the valley of the Urda-Shalan River towards the Bolshoi Yenisei River, due to the exaration of the ridge saddle, which divided the Bolshoy Yenisei and Angara catchment basins, bifurcated and joined with the Jom-Bolok River Valley glacier. A new open-ended glacial valley was formed, which was inherited by the Urda-Shan River after the glaciers melted. This is a typical example of the interception of the riverbed by the neighboring valley due to glacial morphogenesis. With the formation of Lake Khara-Nur, its waters, in turn, through the narrow bottleneck of the segment, entered 

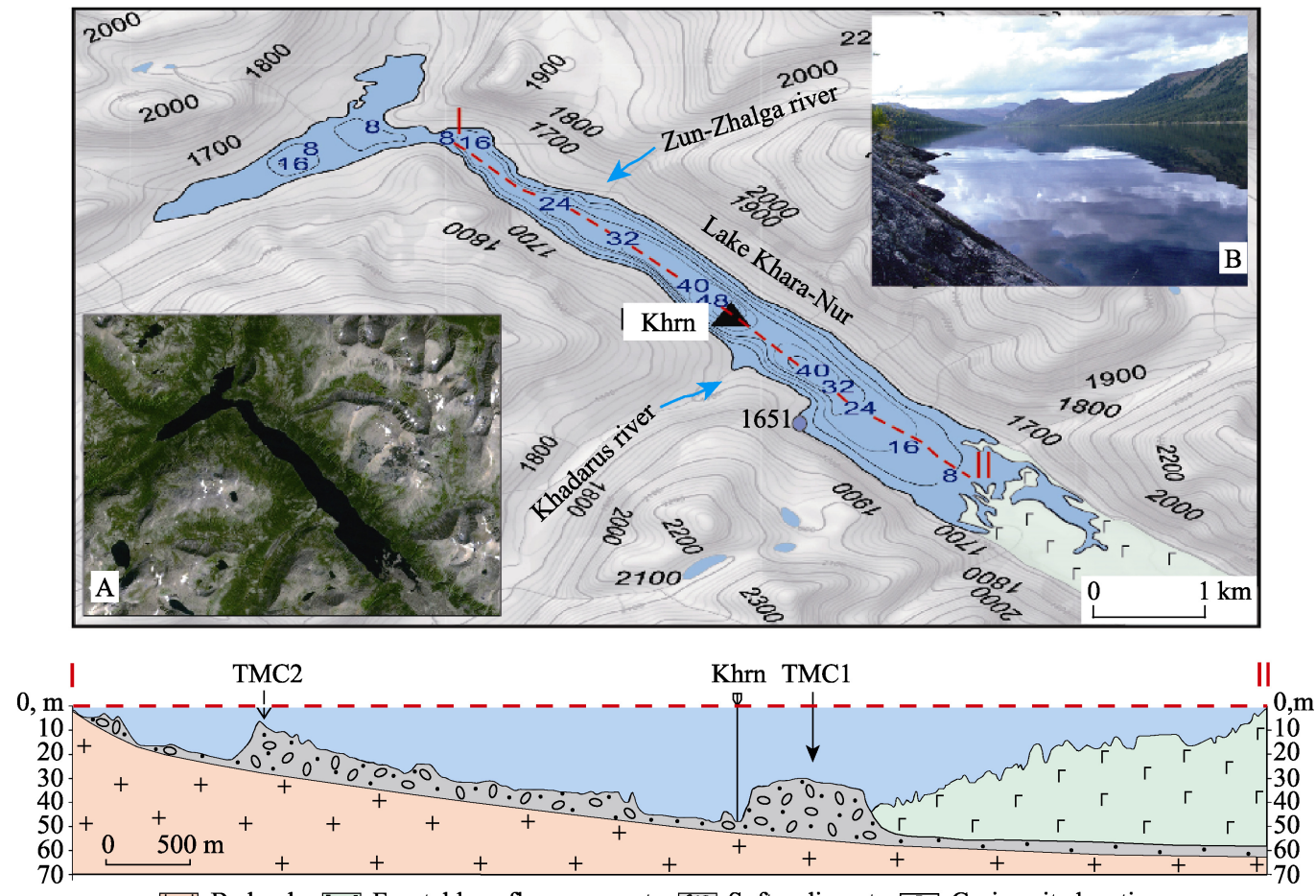

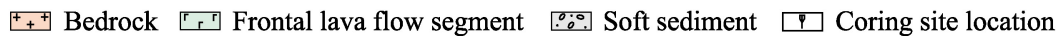

Figure 6 Bathymetric plan of the Lake Khara-Nur (contours are digitized in meters), the black triangle shows the sampling point of the Khrn core. I-II - the lengthwise geological-geomorphological section of the lake basin. The arrows show terminal moraine complexes (TMC). A - a space image of the Lake Khara-Nur location (Image (C) 2017 DigitalGlobe); B - the Lake Khara-Nur, view from the south-east (Picture taken by the authors)

the valley of the Urda-Shan River. During winter in low water, the water level in the lake generally decreases below the threshold of this bridge, and the lake is divided into two separate bodies of water.

According to the received bathymetric data, the bottom of the main lake basin contains two terminal moraine complexes (TMC), located in the ranges of the lateral tributary valleys of the Khadarus and Zun-Zhalga rivers (Figure 6). However, its morphology is significantly different. TMC 1, located near the mouth of the Khadarus river valley, has a symmetrical cross-sectional shape, which indicates the TMC lines longitudinally to the position of the Jom-Bolok river and its affiliation to the glacial morphosystem of the Khadarus river valley. TMC 2, located in the valley of the Zun-Zhalga river has the cross-sectional shape of "the one-sided saw" with steep slopes upwards along the valley and the narrow ones in the opposite direction, which is typical of the terminal moraine lines, occupying the cross to the position of the main valley and indicating its formation through the Jom-Bolok river valley.

During volcanic events, spilled lava flows that descended from the Khi-Gol fold penetrated up into the valley of the Jom-Bolok River. The visible extension of this lava appendix is $4 \mathrm{~km}$, and its front part is flooded with the waters of Lake Khara-Nur. To the west of TMC 1, the depths of the lake reach $51 \mathrm{~m}$, while on the east side at the bottom of the valley you can see a stable settlement of the water basin, and the depths here do not exceed $40 \mathrm{~m}$. It seems obvious that in the valley the depth of the lake should increase, adjusting its depth, 
but this is not happening, which indicates that the lava flow reaches the base of the TMC 1 and marks the limits of its underwater segment.

Another type of volcanic lakes in the valley of the Jom-Bolok River is the multitude of water basins in the lakes flowing surface gaps. A wide, covered with difficult to traverse basalt hummocks, mounds, and Hornitos, Jom-Bolok lava flow surface sank in many places during its cooling, thus forming closed gaps of peculiar forms, some of which were filled with water. The depths of these differ in sizes (from the first tens of square meters to the first square kilometers) the water basins reach 15-20 m. The largest lakes are located in the segments where the direction of the strike of the valley is changing, where lava flows decreased and experienced maximum surface deformations during cooling. An example of this is Olon-Nur, a system of lakes of running water, connected to each other by short water flows (up to 50-100 m), sometimes between lava. A coastline of these water reservoirs has a very rough shape, following the smallest irregularities of relief on the surface of the lava flows.

The Jom-Bolok river reaches Lake Bursuk-Nur through the underground channels. Then it flows through the narrow, full of rapids and winding riverbed, attributed to the axial, most subsided part of the lava flow. Along with all its routes, the bed of the river is accompanied by the chains of small lakes without drainage in the depressions of the lava surface.

\subsubsection{The lakes of glacial origin}

The lake basins of this group are of the highest morphogenetic diversity and multitude. Traces of the exarational-accumulative activity of the Late Pleistocene glaciers is widely spread and are present in all relief belts of the Jom-Bolok volcanic region. The peaks of the bald mountain belts are decorated with an ornament of glacial cirques, the bottoms of which are often occupied by lakes. Thick covers of moraine sediments do not only pave the bottoms of the Jom-Bolok region trough valleys, but also laid over wide peneplained water-divide areas of the Oka Plateau. Depressions in the knob-and-kettle relief of their surface are also occupied by multiple lakes.

Here we distinguish moraine-damming, moraine and corrie lakes.

An example of the moraine-damming lakes is the Lake Tukhuren-Nur, located in the upper reaches of the Barun-Khadarus river valley (see Figures 4 and 5). It occupies an area of $0.8 \mathrm{~km}^{2}$, the true altitude of its water level is $1999 \mathrm{~m}$, and its depth is $8 \mathrm{~m}$. The valley here is trough-shaped, starting with a glacial cirque, a poorly defined shallow sloped arched bank of the terminal moraine is located at a distance of $3 \mathrm{~km}$ from the cirque, forming the Tukhuren-Nur dam. The lake is flow-through. The western part of its basin almost does not have a loose sedimental cover and is made up of bedrock. Currently this water reservoir belongs to the Sentsa river basin, however, the upper part of the Barun-Khadarus river valley, where the lake is located, previously was a part of the Jom-Bolok river valley. As with the segment of the valley, where the Lake Khara-Nur is located, where the riverbed was also intercepted by the neighboring valley as a result of a Late Pleistocene glacial morphogenesis. Though acquiring a new area of the drainage basin of the Bolshoy Yenisei river valley, the Jom-Bolok river valley lost almost the same square area of its own valley after the glaciation.

In the middle of the Lake Tukhuren-Nur at the depth of $8 \mathrm{~m}$, we collected the core of its bottom sediments. The thickness of the probed cross-section is $98 \mathrm{~cm}$. The sediments consist of lake silts, underlying by blue glacial clays with interlayers of rubble-scree material. The age of the glacial sediments at the depth of $98 \mathrm{~cm}$ is $13209 \pm 113$ calibrated years (Table 1) 
Thus, during the interstage Alleroed warming, the glacier of the Barun-Khadarus valley retreated to the upper reaches of its valley. The calculated average rate of sedimentation in the lake is $7.42 \mathrm{~cm} / \mathrm{ka}$.

The lakes in the closed depressions on the surface of the main moraine are small in size, rarely exceeding $0.5 \mathrm{~km}^{2}$, having minor depths and highly irregular coastal lines. They are spread both in the apical mountain belt and on the bottoms of the valleys. We chose as an example the basins, located in the main moraine of the terminal moraine complex in the Jom-Bolok river valley. Glacial sedimentary lines stand out for 20-30 m from under the lava flow, pushing it to the northern slope of the valley. One of such lakes - Borik-Nur (with a true altitude of $1401 \mathrm{~m}$ ) - has an area of $0.4 \mathrm{~km}^{2}$ and is up to $4.5 \mathrm{~m}$ deep (Figures 4 and 7). Most part of the year it is drainless, however, during the rainy season, its basin fills with water and the drainage to the neighboring lake appears. In the dampest years, the drainage can occur through the valley of lateral rupture in the valley of the Oka River.

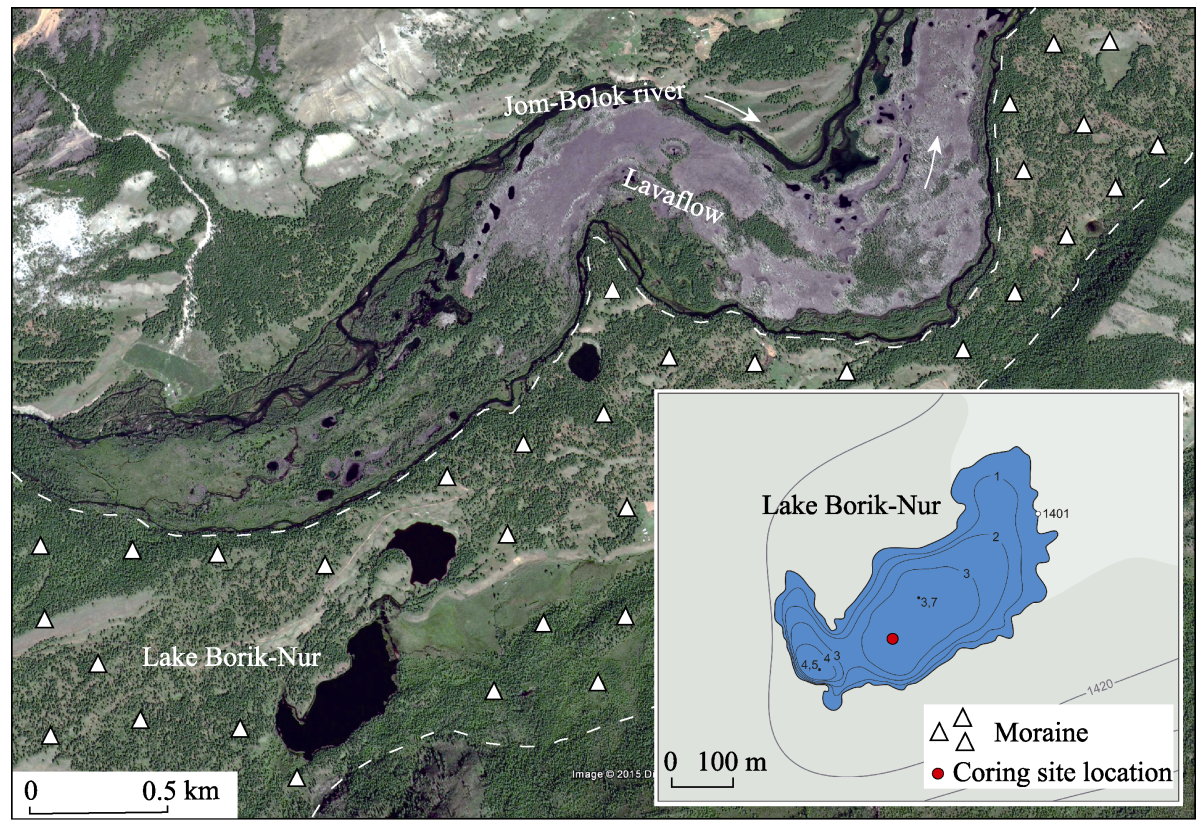

Figure 7 A space image of the Lake Borik-Nur location (Image (C) 2017 DigitalGlobe) and its basin bathymetric plan

The exposed part of the Lake Borik-Nur cross-section (86 cm thick) mostly consists of lake silts. The age of the sediments at the base of the probed section is $4577 \pm 93$ calibrated years (Table 1). The average sedimentation rate on the lake is $18.79 \mathrm{~cm} /$ thousand years. In the lower part of the section the Borik-Nur Lake, sediments become slabby. It seems that the lake dried up while this layer formed.

The next type of the glacial-nival origin lakes is Corrie water reservoirs. This is the most widely spread type of the lakes in the region. The circular shape and low irregularity of the coastal line are typical for them. Corries are often grouped into cirques and line up into cirque stairways, with up to three steps. Sometimes a singular Corrie contains the whole groups of lakes.

An example of the Corrie lakes is the flow-through Lake Khikushka (true altitude of 1956 $\mathrm{m})$, located in the upper reaches of the Khi-Gol fold (Figures 4 and 8). It occupies the lowest 
altitudinal position in the water reservoir cascade of the cirque stairway. Its water surface area is $0.3 \mathrm{~km}^{2}$, with a depth of $43 \mathrm{~m}$. The basin of the lake is separated from the Khi-Gol fold by a narrow bridge, the outer wall of which is closely approached by the lava flow. The bridge is elevated only a few meters above both the surface of the lava flow and the water level of the lake.

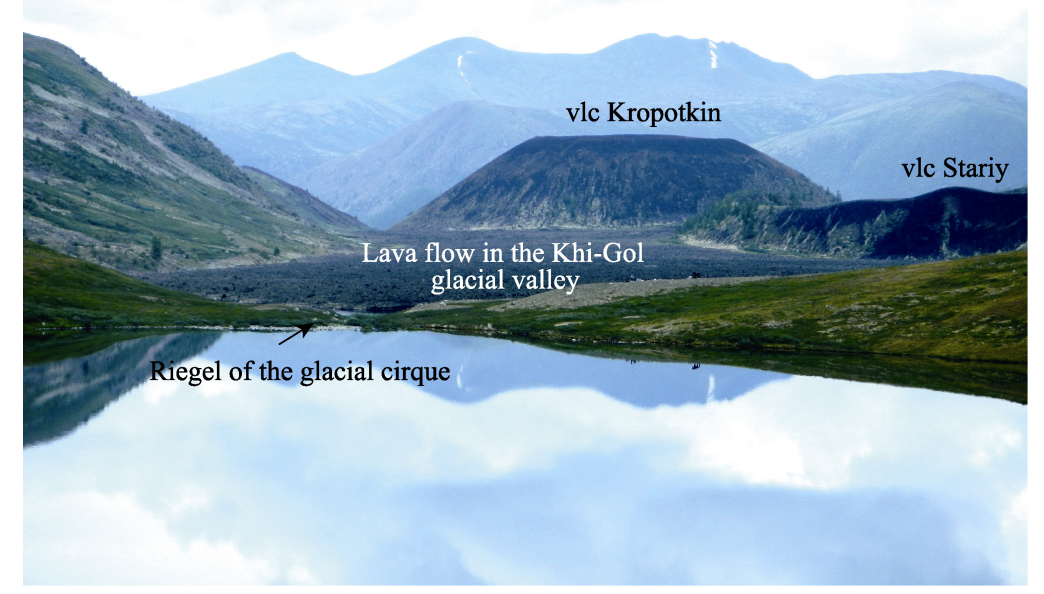

Figure 8 The Khikushka corrie lake at the footing of the Khi-Gol valley volcanoes, view from the south-west. Picture taken by the authors

The Lake Khikushka basin has steep, couloirs cut slopes, with parts of their basement covered with colluvial plumes and combe rock bodies that descend into the lake. The coarse detrital rocks at the bottom of the lake are quickly replaced by the faces of the clay sediments. In the deepest part of the lake, we discovered the lake silts. The thickness of the probe section is $87 \mathrm{~cm}$. The bottom sediments are distinguished by their high terrigenous component, with a fine sorting particle of the clastic material with low roundness. Their age at the base of the section is $9333 \pm 79$ calibrated years (see Table 1). The average sedimentation rate in the Lake Khikushka is $9.32 \mathrm{~cm} / \mathrm{ka}$.

\subsubsection{The lakes of fluvial origin}

This morphogenetic group is presented by floodplain water basins, first of all by oxbows. In general, this lake type is not typical for the high mountain regions of the East Sayan. However, the activation of the modern volcanic activity, accompanied by the formation of the lava dams and the damming of the water flows, created the required conditions for their development. For example, as a result of the Zun-Uhergey lava dam paleolake formation and the damming of the Sentsa river mouth, its local base level of erosion became elevated and following it the level of the bottom-land of the valley began to increase. This led to the stagnant hydrogeological conditions in the lower part of the Sentsa river valley, intensive swamp and lakes formation at its bottom. Sentsa River became highly meandrous and began to produce oxbows, and the sedimentary processes of the lake-swamp-alluvial type activated within the valley.

An example of the floodplain lakes is Lake Nomto-Nur (true altitude $1386 \mathrm{~m}$ ). The area of the reservoir is $0.5 \mathrm{~km}^{2}$ with a depth of about $3.5 \mathrm{~m}$. Its shores are swamped, and the former riverbed is clearly traced at its bottom. The lake has a close hydrological connection 
with the Sentsa river and is a consumer of its solid flow. It is connected to the river by a channel, through which the flow usually occurs. However, during the summer floods, the water level rises and the channel starts to function in the opposite direction, filling the Nomto-Nur basin not only with liquid but also with the solid flow. The latter fact is illustrated by the presence of the elongated beak-shaped delta where the channel inflows into the lake.

The Lake Nomto-Nur bottom sediments are represented mostly by homogenous lake silts with the layer of the finely sorted aleurite in the depth range $63-68 \mathrm{~cm}$. At the depth of $127 \mathrm{~cm}$, the age of the sediments is $2769 \pm 22$ calibrated years. The sedimentation rate in the lake is $45.87 \mathrm{~cm} / \mathrm{ka}$. It is worth mentioning, that these are the highest sedimentation rates among all Jom-Bolok volcanic region morphosystems we studied. The Zun-Uhergey paleolake in the Oka river valley has long ceased to exist, however, the morpholithodynamic processes, started because of its formation and, as a result, the Sentsa base level of erosion change, continue to develop up to this day.

\subsubsection{The lakes of the complex origin}

The last group of the lakes consists of the lake basin of complex origin, formed under the conditions of several processes, equally important in the relief-forming impact. First of all, these are water reservoirs of the glacial-accumulative genesis (moraine), their basins were later affected by fluvial processes. An example of such lakes is spread in the lower reaches of the Sentsa river valley, where the large terminal moraine complex with lots of closed basins, occupied by lakes, is located. During the elevation of the local erosion level of the Sentsa River, and the following elevation of its floodplain level, along with the formation of the lava-dammed Zun-Uhergey paleolake, the glacial lakes of the terminal moraine complex became flooded. The erosion processes started to refine the knob-and-kettle relief of the moraine, and the alluvial sediments started to compensate its depressions. Glacial-fluvial lake morphosystems emerged.

An example of such formations is the Lake Shas-Nur (true altitude of $1363 \mathrm{~m}$ ). Its area is $0.3 \mathrm{~km}^{2}$, and the depth does not exceed $4 \mathrm{~m}$. From the north, the coastal line has a complex configuration, repeating the smallest relief irregularities of the subaerial relief of the moraine, and from the east, where it connects to the Sentsa riverbed through the system of the floodplain reservoirs, the basin of the lake is influenced by alluvial processes. Its basin is actively loaded with river sediments in the same manner as described for the Nomto-Nur Lake, except that the amount of solid matter reaching the Shas-Nur Lake is different. A smaller amount of this material gets into Shas-Nur Lake, so a considerable amount is captured by the collectors in the intermediate floodplain. However, mean sedimentation rate of the lake is very high and reaches $31.90 \mathrm{~cm} / \mathrm{ka}$.

The sediments of Shas-Nur Lake were probed to the depth $192 \mathrm{~cm}$. The lake sediments consist of silt with high organic component, rhythmically interlayed with thin layers of clays, aleurite and hydrotroilite. The bottom of section $(152-188 \mathrm{~cm})$ comprises massive aleuritic clay. The overall thickness of sediments reaches $5 \mathrm{~m}$; their age at a depth of $192 \mathrm{~cm}$ is measured as $6019 \pm 72$ calibrated years.

The lakes of the complex origin involve thermokarst water reservoirs, their formation and development are due to formation of glacier relief and alluvial processes in the swamped areas of the river valley bottoms. Such reservoirs started to appear in the deglaciation period, primar- 
ily on the main moraines; they still emerge in the lowland areas of the river floodplains as very small-sized spots, rarely exceeding $0.005 \mathrm{~km}^{2}$. Such reservoirs have not been mapped so far.

\subsection{Jom-Bolok volcanic environment and climate dynamics during Holocene based on complex analysis of Khara-Nur Lake sediments}

It is noteworthy that in the surveyed region the Khara-Nur is a truly large lake of volcanic origin. In 2013 the bottom sediments were drilled with UWITEC gravity corer. A core of $130 \mathrm{~cm}$ in length was taken up from the water depth of $47 \mathrm{~m}$.

\subsubsection{Sediments}

(1) Lithology and chronology. The lacustrine silts make up upper $94 \mathrm{~cm}$ of the core. In the range of 94-102 cm from top the core displays intercalation of peaty soils and clays (Figure 9). Clayish sand bearing organic matter and thin layers of peaty soils dominate within the interval of $102-117 \mathrm{~cm}$, and the peaty soils are exposed in the layer of $118-127 \mathrm{~cm}$. The soils are underlain by the 3 rd layer of sands with organics. The core bottom contains peaty soil layer only $1 \mathrm{~cm}$ thick.

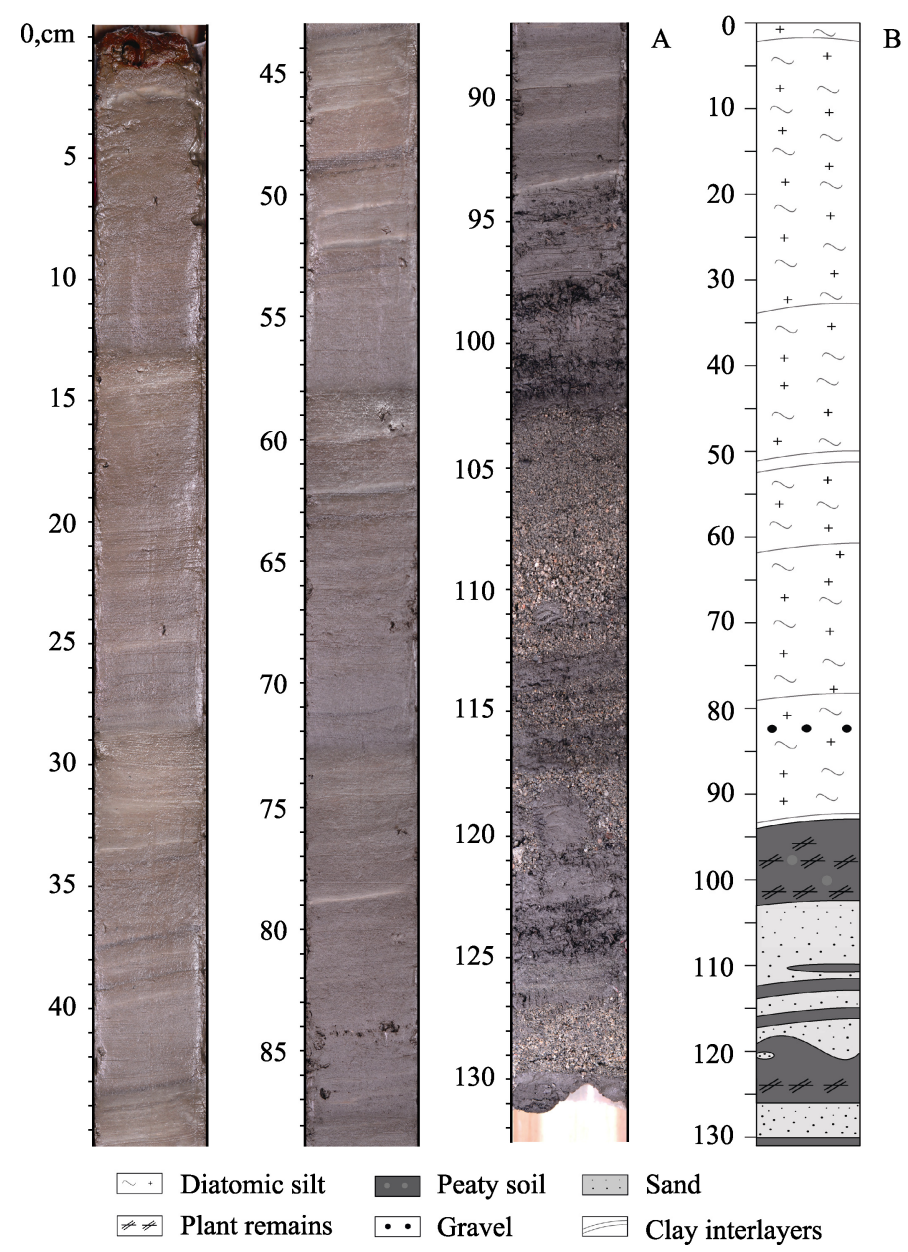

Figure 9 The photo of the Khrn core (A) and its lithological column (B) 
At a depth of $127 \mathrm{~cm}$ the age of the sediments is evaluated as $6881 \pm 53$ calibrated years (Table 1). The average sedimentation rate is $19.04 \mathrm{~cm} / \mathrm{ka}$, though significantly varying between the two dated levels (Figure 10).

(2) Magnetic susceptibility (MS) values for the Khara-Nur Lake (Figure 11) vary from 200 to 700 units in the range of 130-102 cm (around 68986400 years ago). In the other core interval its values vary between 20 and 90 units.

Drastic decrease of MS, high content of organic matter (LOI) indicate weakening of terrigenous and strengthening of biogenic sedimentation later than 6400 years ago, determined by the change of sedimentological conditions (complete damming of the riverbed and formation of lake) and dilution of magnetic minerals by inflow from the lake water drainage area. Since that time, the $\mathrm{SiO}_{2 \text { bio }}$

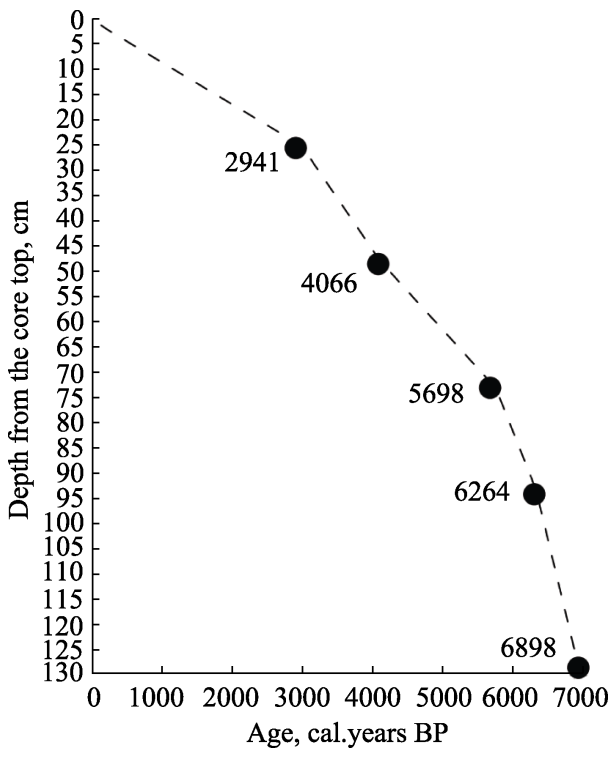

Figure 10 Age-depth relationship of the Khrn core from Lake Khara-Nur concentration in the sediments increases, pointing to increase in productivity of the already formed water reservoir.

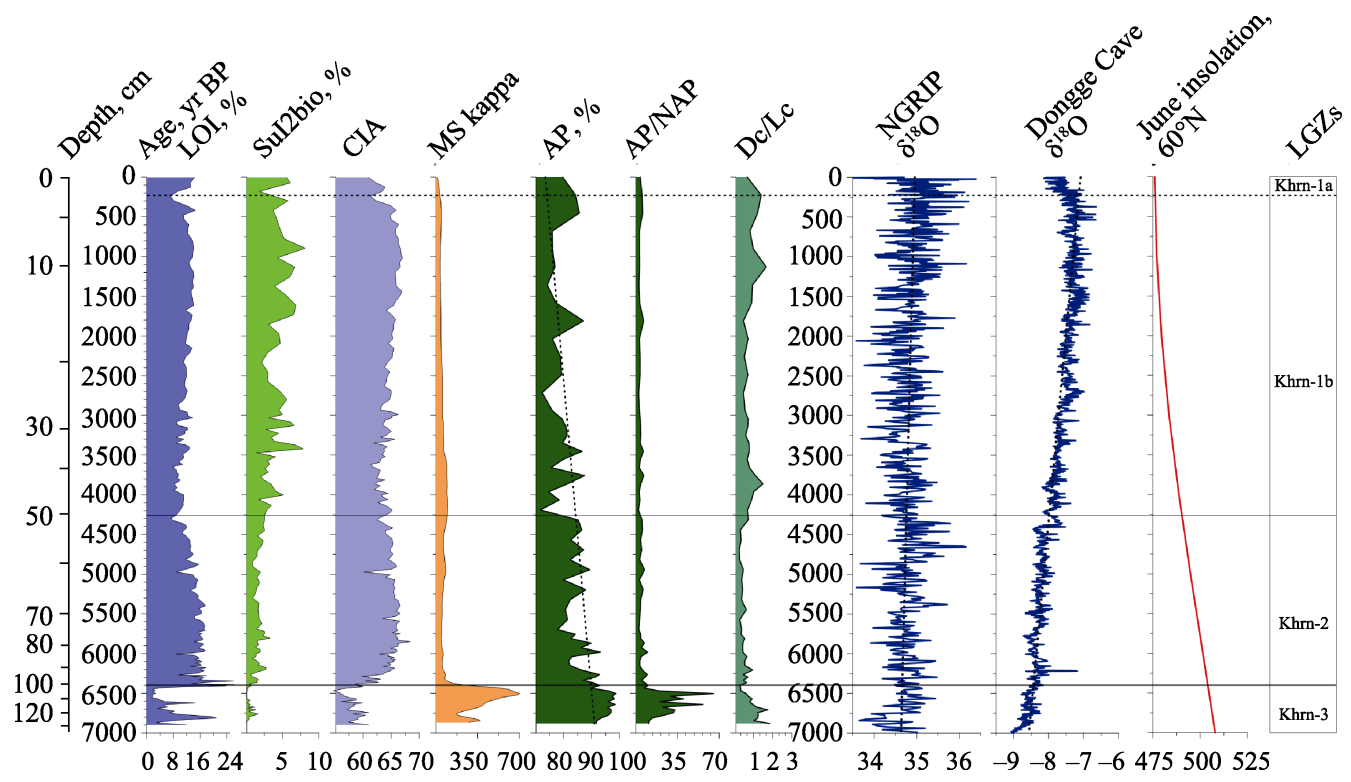

Figure 11 Comparison of the selected environmental indexes from the Khara-Nur lake sediments (this study), the NGRIP $\delta^{18} \mathrm{O}$ record from Greenland, as indicator of the Northern Hemisphere air temperature (after Svensson et al., 2008) and $\delta^{18} \mathrm{O}$ record from Chinese stalagmites (Dongge Cave, after Wang et al., 2001; Yuan et al., 2004), as indicator of the Pacific monsoon intensity, the Northern Hemisphere June insolation at $60^{\circ} \mathrm{N}$ (after Berger and Loutre, 1991), plotted along their respective time scales. LOI - loss on ignition, AP - arboreal pollen, NAP non-arboreal pollen, MS - magnetic susceptibility, DC - dark conifers, LC - light conifers, LGZs - local geoecological zones, CIA $\left(\mathrm{Al}_{2} \mathrm{O}_{3} /\left(\mathrm{Al}_{2} \mathrm{O}_{3}+\mathrm{CaO}+\mathrm{Na}_{2} \mathrm{O}+\mathrm{K}_{2} \mathrm{O}\right)\right)^{*} 100$ - chemical index of alteration (Nesbitt, Young, 1982) 
(3) Palynological indexes. The Khrn-3 zone (130-102 cm from the top of the core, or 6898-6400 years ago) has the highest concentrations of the arboreal pollen (AP) and the AP to non-arboreal pollen (NAP) ratio. The values of DarkC/LightC are above 1. For Khrn-2 (10-48 cm from top, 6400-4100 years ago) the AP and AP/NAP values typically decrease. That of DarkC/LightC is below 1. The DarkC/lightC values rise again in the Khrn-1b subzone (47-6 cm, 4100-650 years ago). In the Khrn-1a $(6-0 \mathrm{~cm}, 650$ years ago to the present day) the values of all indexes compared to the previous subzone increase (Figure 11).

(4) Geochemical indexes and physical properties of the sediments. In the Khrn-3 zone the minimal $\mathrm{SiO}_{2 \text { bio }}$ values are the case. The LOI and CIA values are low and change considerably. In the Khrn-2 zone the $\mathrm{SiO}_{2 \text { bio }}$ values are gradually increasing, the LOI and CIA values rise significantly and become steadily high. In the Khrn-1b the LOI and CIA values mildly decrease and then increase again, while the $\mathrm{SiO}_{2 \text { bio }}$ concentration keeps increasing. In the Khrn-1a zone the tendency for decrease is clearly seen in the concentrations of $\mathrm{SiO}_{2 \text { bio, }}$ LOI and CIA (Figure 11).

\subsubsection{Environment and climate stages}

It was found that in time span around 6898-6400 years ago the layers of clayish sand rich in organic matter and peat were derived. According to the total core data, the basal layer formation was characterized by river (occasionally bog) sedimentation in the center of Khara-Nur Lake in its current shape. Maximal AP values, especially for dark coniferous, suggest existence of forests near the sampling point, since pollen of dark coniferous trees settles primarily under the canopy (Bezrukova et al., 2005). The climate was moderately cold and much more humid than today, with the average annual precipitation above $500 \mathrm{~mm}$, that is required for the dark coniferous forests (Bezrukova et al. 2016). The low $\mathrm{SiO}_{2 \text { bio }}$ concentrations in sand and soil layers, maximal MS values point to the accumulation of primary mineragenic material within the riverbed and/or sometimes within the river floodplain.

The key record of climate change in the Northern Hemisphere (Figure 11) shows the highest level of summer insolation during this period, heightened average air temperatures in the Northern Hemisphere. The development of woody vegetation in the Khara-Nur Lake basin was maximal 6880-6400 years ago, thus being in line with the Holocene optimum in the global records (Figure 11, Oxygen-Isotopic scales).

The later stage of the natural environment, 6400-4100 years ago matches the onset of lacustrine silt accumulation around 6400 years ago (Figure 11, Khrn-2). The reduced abundance of the arboreal pollen (AP/NAP), especially dark coniferous pollen (Figure 11) can be attributed to the post-optimal cooling, deeper soil freezing due to permafrost. However, it is worth pointing out that about 6400 years ago in the Khara-Nur paleo lake silts started to accumulate instead of river sands with organics and peat (Figure 11). The other very important reason for the local forest degradation could, therefore, be flooding of coastal forests through the water of the newly formed lake. The gradually increasing $\mathrm{SiO}_{2 \text { bio }}$ values in the interval of 6400-4100 years ago are explained by the development of the siliceous organisms, primarily diatom algae, in the lake water reservoir. The rapid drop of MS suggests the onset of lake sedimentation, increase of depth for core sampling point, where the coarse terrigenous material arrived no more. The increase in the CIA values in the range of 6400-4100 years ago, compared to the previous interval is determined both by the change of sedimenta- 
tion type and cooling.

During the time range 4100-650 years ago in the lake area forest vegetation keeps reducing (Figure 11). However, the expansion of the dark coniferous associations could be caused by the atmospheric humidity increase. Within the lake itself, the diatom algae keeps developing, which is reflected in the $\mathrm{SiO}_{2}$ bio increase. A short episode of the CIA and $\mathrm{SiO}_{2}$ bio values decrease around 4100-3600 years ago with the simultaneous increase in the MS signaling the change of the erosional activity in the lake watershed, and the volumes of the inflow into the lake terrigenous material caused by increasing atmospheric precipitation.

Later, around 650 years ago till the present day, the area of the forest vegetation somewhat raised in the lake basin (Figure 11). The CIA decrease is coherent with possible increase of the vegetation cover density, development of richer soil cover, which triggered chemical weathering processes and inflow of mobile elements into lake sediments.

\section{Discussion and conclusions}

With the data acquired by the lake research in mind, the authors made up the morphogenic classification of lake basins situated in the Jom-Bolok volcanic region: (1) lakes of volcanic origin: dammed by lava flows, inside the lava-flow surface gaps, crater lakes; (2) lakes of glacial origin: lakes with moraine-dammed, moraine and corries; (3) lakes of fluvial origin floodplain lakes; (4) lakes of complex origin.

It was found out that mostly widespread are the limnic morphosystems of volcanic and glacial origin. The reservoirs of fluvial and complex genesis are not as significant. All of them were formed in the Late Glacial and Holocene times. The limnic morphogenesis dynamically developed under conditions of alpine relief, high energy of neotectonic and exogenic processes.

With available radiocarbon dates on lake sediments we managed for the first time the calculation of the average sedimentation rates within the water reservoirs. They considerably differ and vary, primarily due to the lakes geomorphological position. In the glacial lakes encompassed by the bald mountain belt, the average sedimentation rate is usually 7 to 10 $\mathrm{cm} /$ thousand years, while in the reservoirs of volcanic genesis they reach $20 \mathrm{~cm} /$ thousand years. With the avalanche values (up to $45.87 \mathrm{~cm} /$ thousand years) the sedimentation rates approach in the floodplain reservoirs in the Sentsa River valley. Thus, the morphologic-lithodynamic processes transformed due to the temporary damming effect; they continue to develop actively, the stagnation conditions in the lower reaches of the Sentsa Valley are still preserved, despite the fact that the dammed lake ceased to exist, and the local erosion level was reverted to its initial state.

The Khara-Nur Lake, the largest one in the surveyed region, represents the major unit of its limnic landscapes. It emerged around 6400 years ago because of the lava flow damming of the upper reaches of the Jom-Bolok River. The complex record on the Jom-Bolok region environment, acquired from its sediments made it feasible to identify the long-term tendencies of mountainous geosystems in the Mid- and Late Holocene.

The first sedimentary record of the Khara-Nur Lake disclosed the general trend of the forest vegetation reduction within the Jom-Bolok region during the last 7000 years. The acquired results were helpful in defining the initial period when the sediments accumulated in the river floodplain in the warmer and humid, compared to the current one, climate of the 
Holocene optimum around 6889-6400 years ago. The other important change in the natural environment and climate 4100 years ago corresponds to the beginning of the Neoglacial period.

Thus, bottom sediments of the Jom-Bolok valley lakes contain uninterrupted records of the Holocene vegetation, landscapes, climate history of this region. Primary studies showed the importance and a high potential of the Jom-Bolok lake records for understanding the environment history of South Siberia in Holocene in terms of global changes.

\section{References}

Adamovich A F, Grossvald M G, Zonenshain L P, 1959. New data on Kropotkin and Peretolchin volcanoes. Transactions of All-Union Aerogeology Trust, 5: 79-90. (in Russian)

Amosova A A, Panteeva S V, Chubarov V M et al., 2016. Determination of major elements by wavelength-dispersive X-ray fluorescence spectrometry and trace elements by inductively coupled plasma mass spectrometry in igneous rocks from the same fused sample $(110 \mathrm{mg})$. Spectrochimica Acta Part B: Atomic Spectroscopy, 122: 62-68.

Arzhannikov S G, Braucher R, Jolivet M et al., 2012. History of Late Pleistocene glaciations in the central Sayan-Tuva Upland (southern Siberia). Quaternary Science Reviews, 49: 16-32.

Arzhannikov S G, Ivanov A V, Arzhannikova A et al., 2017. Age of the Jom-Bolok lava fields according to dendrochronological and radiocarbon data. Russian Geology and Geophysics, 1: 27-47.

Berger A, Loutre M F, 1991. Insolation values for the climate of the last 10 million years. Quaternary Science Reviews, 10(4): 297-317.

Bezrukova E V, Abzaeva A A, Letunova P P et al., 2005. Post-glacial history of Siberian spruce (Picea obovata) in the Lake Baikal area and the significance of this species as a paleo-environmental indicator. Quaternary International, 136: 47-57.

Bezrukova E V, Shchetnikov A A, Kuzmin M I et al., 2016. First data on the environment and climate change within the Jom-Bolok Volcanic Field (Eastern Sayan Mountains) in the Middle-Late Holocene. Doklady Earth Science, 468(3): 527-531.

Bronk Ramsey C, 2009. Bayesian analysis of radiocarbon dates. Radiocarbon, 51(1): 337-360.

Colman S M., Jones G A, Rubin M et al., 1996. AMS radiocarbon analyses from Lake Baikal, Siberia: Challenges of dating sediments from a large, oligotrophic lake. Quaternary Science Reviews, 15: 669-684.

Demske D, Heumann G, Granoszewski W et al., 2005. Late glacial and Holocene vegetation and regional climate variability evidenced in high-resolution pollen records from Lake Baikal. Global and Planetary Change, 46: 255-279.

Faegri K, Iverson J, Kaland P E et al., 1989. Textbook of Pollen Analysis. New York: Wiley, 579.

Gillespie A R, Burke R M, Komatsu G et al., 2008. Late Pleistocene glaciers in Darhad basin, northern Mongolia. Quaternary Research, 69: 169-187.

Grimm E C, 1987. CONISS: A Fortran 77 program for stratigraphically constrained cluster analysis by the method of incremental sum of squares. Computer Geoscience, 13: 13-35.

Grosswald M G, 1965. Development of Relief in the Sayan-Tuva Highland. Moscow: Nauka, 166. (in Russian)

Heiri O, Lotter A F, 2001. Effects of low count sums on quantitative environmental reconstructions: An example using subfossil chironomids. Journal of Paleolimnology, 26: 343-350.

Ivanov A V, Arzhannikov S G, Demonterova E I et al., 2011. Jom-Bolok Holocene volcanic field in the East Sayan Mts., Siberia, Russia: Structure, style of eruptions, magma compositions, and radiocarbon dating. Bulletin of Volcanology, 73: 1279-1294.

Kiselev A I, Medvedev M E, Golovko G A, 1979. Volcanism of the Baikal Rift Zone and Deep-Seated Magma Formation Problems. Moscow: Nauka, 164. (in Russian)

Komatsu G, Arzhannikov S G, Gillespie A R et al., 2009. Quaternary paleolake formation and cataclysmic flooding along the upper Yenisei River. Geomorphology, 104: 143-164. 
Krivonogov S K, Sheinkman V S, Mistryukov A A, 2005. Ice damming of the Darhad paleolake (Northern Mongolia) during the late Pleistocene. Quaternary International, 136: 83-94.

Kropotkin P A, 1867. A trip to the Oka Guard Post. Memoirs of the Russian Geographical Society, Siberian Division. Irkutsk: Book, 9-10. (in Russian)

Mann M E, Zhang Z, Rutherford S et al., 2009. Global signatures and dynamical origins of the Little Ice Age and Medieval Climate Anomaly. Science, 326: 1256-1260.

Minyuk P S, Borkhodoev V Y, Wennrich V, 2014. Inorganic geochemistry data from Lake El'gygytgyn sediments: Marine isotope stages 6-11. Climate of the Past, 10: 467-485.

Moberg A, Sonechkin D M, Holmgren K et al., 2005. Highly variable Northern Hemisphere temperatures reconstructed from low- and high-resolution proxy data. Nature, 433: 613-617.

Mortlock R A, Froelich P N, 1989. A simple method for the rapid determination of biogenic opal in pelagic marine sediments. Deep Sea Research, 36: 1415-1426.

Nesbitt H W, Young G M, 1982. Early Proterozoic climates and plate motions inferred from major element chemistry of lutites. Nature, 299: 715-717.

Obruchev S V, Lurye M L, 1954. Kropotkin and Peretolchin volcanoes in East Sayan. Transactions Laboratory of Volcanology, 8: 210-225. (in Russian)

Pashkova G V, Aisueva T S, Finkelshtein A L et al., 2016. Analytical approaches for determination of bromine in sediment core samples by X-ray fluorescence spectrometry. Talanta, 160: 375-380.

Sharastepanov B D, 2007. Natural landscapes of the Oka Plateau and their use for tourist and recreational purposes. (Dr. Sci. (Geogr.) dissertation Thesis). 152. (in Russian)

Solovyova L N, 1976. Morphology of the Cryolithozone of the Sayan-Baikal Region. Novosibirsk: Nauka, 126. (in Russian)

Svensson A, Andersen K K, Bigler M et al., 2008. A 60000 year Greenland stratigraphic ice core chronology. Climate of the Past, 4: 47-57.

Wang Y J, Cheng H, Edwards R L et al., 2001. A high-resolution absolute-dated Late Pleistocene Monsoon record from Hulu Cave, China. Science, 294: 2345-2348.

Yarmolyuk V V, Lebedev V I, Sugorakova A M, 2001. Eastern Tuva area of the youngest volcanism of Central Asia: Stages, products, and character of volcanic activity. Vulkanologiya i Seismologiya, 3: 3-32. (in Russian)

Yarmolyuk V V, Nikiforov A V, Ivanov V G, 2003. The structure, composition, sources and mechanism of Jombolok valley lava flows (Holocene, South-Baikal volcanic area). Vulkanologiya i Seismologiya, 5: 41-59. (in Russian)

Yuan D X, Cheng H, Edwards R L et al., 2004. Timing, duration, and transitions of the Last Interglacial Asian monsoon. Science, 304: 575-578. 